\title{
Palacios pintados: un recorrido desde la ficción a la realidad (Lancelot du Lac y Castel Roncolo)
}

\author{
José Manuel Lucía Megías \\ Universidad Complutense de Madrid \\ Jmlucia@filol.ucm.es
}

A Claudia Demattè

compañera en tantos viajes caballerescos

\section{RESUMEN}

En este trabajo asistimos a una magnífica interacción entre literatura, arquitectura y pintura. Del palacio pintado que aparece en la habitación de Lanzarote del Lago en el palacio de la Floresta de Morgana se pasa a la literatura pintada en Castel Roncolo.

Palabras clave: Lanzarote del Lago, Castel Roncolo, pintura bajomedieval.

\section{Painted palaces: a journey from fiction to reality \\ (Lancelot du Lac and Castel Roncolo)}

\begin{abstract}
This paper focuses on the interaction between literature, architecture and painting. The article goes from the painted room in the Floresta palace of Morgana, described in the arturic novels, to the literary scenes depicted in the walls of Castel Roncolo.
\end{abstract}

Key words: Lancelot, Castel Roncolo, Late Medieval Frescoes. 


\section{El viaje literario: la habitación pintada de Lanzarote del Lago en el palacio de la floresta de Morgana}

Jacques d'Armagnac es uno de los nobles bibliófilos más curiosos e interesantes del siglo XV francés. Hombre de su tiempo, protagonista de muchas de las intrigas palaciegas alrededor de la controvertida figura de Luis XI, heredó gran parte de la biblioteca de su bisabuelo, el conocido bibliófilo Jean de Berry (entre ellos, los códices artúricos BNF fr 117-120). Murió en 1477, con 44 años, ejecutado en París acusado de alta traición, por haber participado en la Liga del Bien Público un año antes. Pero a pesar de su corta vida -en términos relativos, claro está- y de las múltiples intrigas en que apareció su nombre, Jacques d'Armagnac tuvo tiempo para reunir una imponente biblioteca, y mantuvo a su cargo a los copistas locales Gilles Gracien (o Gassien) y Michel Gonnot, así como al iluminador Evard d'Espinques, que realizaron muchos de los códices para su biblioteca. Sus manuscritos se identifican claramente no solo por su escudo en las orlas iniciales, sino por una inscripción escrita por él mismo al final de los mismos donde da cuenta de los folios copiados y de las historias contenidas en él ${ }^{1}$.

Uno de los códices copiados e iluminados en su particular scriptorium es el Lancelot du Lac, mandado copiar entre 1470 y 1475. En la actualidad, encuadernado en cuatro volúmenes, se conserva en la Bibliothèque Nationale de France (fr. 113-116) ${ }^{2}$. Su pasión por la literatura artúrica se aprecia en otro espectacular códice que termina de copiarse el 8 de octubre de 1463: Roman de Tristan (BNF, fr. 99) y que también encarga Jacques d'Armagnac a idénticos copistas e iluminador. De la mano de algunas miniaturas de los códices fr. 113-116 nos adentraremos en una de las aventuras más conocidas de la Vulgata artúrica: la prisión de Lanzarote por parte de Morgana y la ocasión fortuita que tendrá el hada para vengarse de Ginebra, de su odiada cuñada Ginebra, venganza que será el principio del final del rey Arturo y de los caballeros de la Mesa Redonda, y que tiene su origen en una camera picta ${ }^{3}$.

La literatura artúrica, el engranaje de textos, leyendas y lecturas que comenzaron a dar forma Wace, Chrètien de Troyes, María de Francia y Robert de Boron en el siglo XII, se prosificaron en el siglo XIII en extensas compilaciones narrativas que conocemos con los títulos de Vulgata (hacia 1215-1230) y Pseudo-Boron (1230-1240) ${ }^{4}$. La Vulgata artúrica organizará la materia artúrica -mezclándose en muchos de los códices con las aventuras de Tristán- en cinco libros, que van desde la Estoire de

1 Para profundizar en el tema, véase F. AVRIL y N. REYNAUD, Les manuscrits à peintures en France (1440-1520), Paris, 1994, esp. pp. 164-167.

2 Reproducción facsímil de los códices puede consultarse en Gallica (http://gallica.bnf.fr), y en la exposición virtual La légende du Roi Artur (http://expositions.bnf.fr/arthur/index.html)

3 Véase sobre este tema, R. TRACHSLER, "Lancelot, seigneur de la joyeuse garde", Clotûres du cycle arthurien, Genève, 1996, pp. 67-141.

4 Desde las investigaciones de J.C. MIRANDA, A Demanda do Santo Graal e o Ciclo Arturiano da Vulgata, Porto, 1998, es preferible hablar de la compilación del "Pseudo-Boron" antes que el término anterior "Post-vulgata", cuya existencia textual completa está siendo muy cuestionada en los últimos tiempos. Para los textos hispánicos, puede ampliarse la información con el artículo de R.M. MÉRIDA JIMÉNEZ, "La 'Materia de Bretaña' en las culturas hispánicas de la Edad Media y del Renacimiento: textos, ediciones y estudios”, Revista de Literatura Medieval, 22 (2010), pp. 289-350. 
Saint-Graal a la Morte du roy Artur, quedando en medio: Merlin, Lancelot du Lac y la Quête du Saint-Graal. En esta división textual, la parte dedicada a las aventuras del mejor de los caballeros de la Mesa Redonda, Lanzarote del Lago, será la que ocupe un mayor espacio, y es la que mandará copiar Jacques d'Armagnac, la lectura que más le interesa a finales del siglo XV, que se completa con episodios y aventuras de la Morte du roi Artur, en el ms. fr. $116^{5}$.

Todo comienza cuando Lanzarote entre en el Valle sin Retorno o Valle de los Falsos Enamorados ${ }^{6}$. Morgana, hermana del rey Arturo, que había aprendido todas las artes de la magia de la mano de Merlín, fue engañada por su caballero. Descubiertos por Morgana, tanto fue su pesar que a punto estuvo de perder el juicio. Y bien puede decirse que así fue, pues donde antes había un rico y alegre valle ahora solo puede verse una cárcel, una particular cárcel:

"Extendió entonces por todo el valle sus encantamientos, de tal forma que nunca pudiera entrar en él ningún caballero y luego salir, si le había faltado a su amiga en cualquier cosa, incluso en voluntad"7.

Hasta un total de 253 caballeros estaban presos allí cuando Lanzarote llega al valle, quien después de vencer en varias aventuras, consigue desencantarlo pues su amor por la reina Ginebra es puro y nunca, ni por obra o por pensamiento, la había traicionado. Y este amor puro, causa de la libertad de los caballeros que allí estaban presos y que no se habían comportado con sus damas con tanta fidelidad, será también origen de su desgracia, pues Morgana, al reconocerle y sospechar que ama a la reina Ginebra, piensa el modo de vengarse de su cuñada, la mujer del rey Arturo:

"Morgana hace que lo desarmen con grandes honores y cuando supo que era Lanzarote, sospechó que amaba con amor a la reina; decide que le causará a esta alguna tristeza y piensa hacerlo de tal manera que nunca más vuelva a tener alegría si la reina lo ama tanto como él a ella, pues Morgana odiaba a la reina por encima de todas las mujeres".

Por la noche, gracias a un anillo encantado que hace dormir sin límite a quien lo porta, Lanzarote es llevado por los sirvientes a un palacio que Morgana tiene en lo más profundo del bosque, y en aquella prisión, la primera de Lanzarote, se despierta por la mañana sin entender nada, pues nada a su alrededor le recuerda las salas del día anterior, a los caballeros amigos a los que había liberado y le habían llenado de honores y de alegrías.

\footnotetext{
5 Sobre el programa iconográfico de este grupo de manuscritos, véase ahora I. FABRY-TEHRANCHI, "Le livre de messire Lancelot du Lac: présentation matérielle et composition des manuscrits arthuriens de Jacques d'Armagnac (BNF fr. 117-120 et 113-116)", Actes du 22e congrès de la Société Internationale Arthurienne, Rennes, 15-20 juillet 2008, 2009, pp. 1-38.

6 Se corresponde al capítulo XCIII de la traducción realizada por C. ALVAR, Libro 3. El Valle sin Retorno, Madrid, 1984, p. 838.

7 C. ALVAR, op. cit., 1984, pp. 839.

8 idem., p. 855.
} 
“Al punto se despertó y se vio en aquel lugar negro y odioso, y se quedó sorprendido. Empieza a lamentarse entonces con amargura por mi señor Galván, por mi señor Yvaín, y por el duque, pues le parecía que todo lo que había hecho en el Valle de los Falsos Enamorados no era más que sueño".

Y de este sueño, de esta imaginación le saca la propia Morgana con las siguientes palabras: "Lanzarote, ahora os tengo prisionero, tendréis que cumplir una parte de mis deseos" 10 . Y su deseo no es otro que confirmar de su propia boca que la mujer a quien ama con un amor tan perfecto es la reina Ginebra.

La primera miniatura del BNF fr. 114 que ilustra este episodio tiene como motivo esta primera conversación entre Morgana y Lanzarote del Lago (figura 1). Pero no será la petición de Morgana para confirmar sus sospechas o la negativa de Lanzarote y su enfado ("En verdad, señora, antes de que lo sepáis, habrán pasado todos los días de vuestra vida"), sino el acuerdo al que llegan para que Lanzarote pueda liberar a Galván, como se aprecia en los gestos de las manos:

"Os dejaré ir, pero me prometeréis como leal caballero que vais a volver a mi prisión tan pronto como mi señor Galván sea puesto en libertad por vos o por otro; no daréis a conocer a nadie a qué lugar os dirigís, pero apenas veáis a mi mensajero, vendréis y volveréis a entrar en una prisión como la que ahora tenéis" ${ }^{11}$.

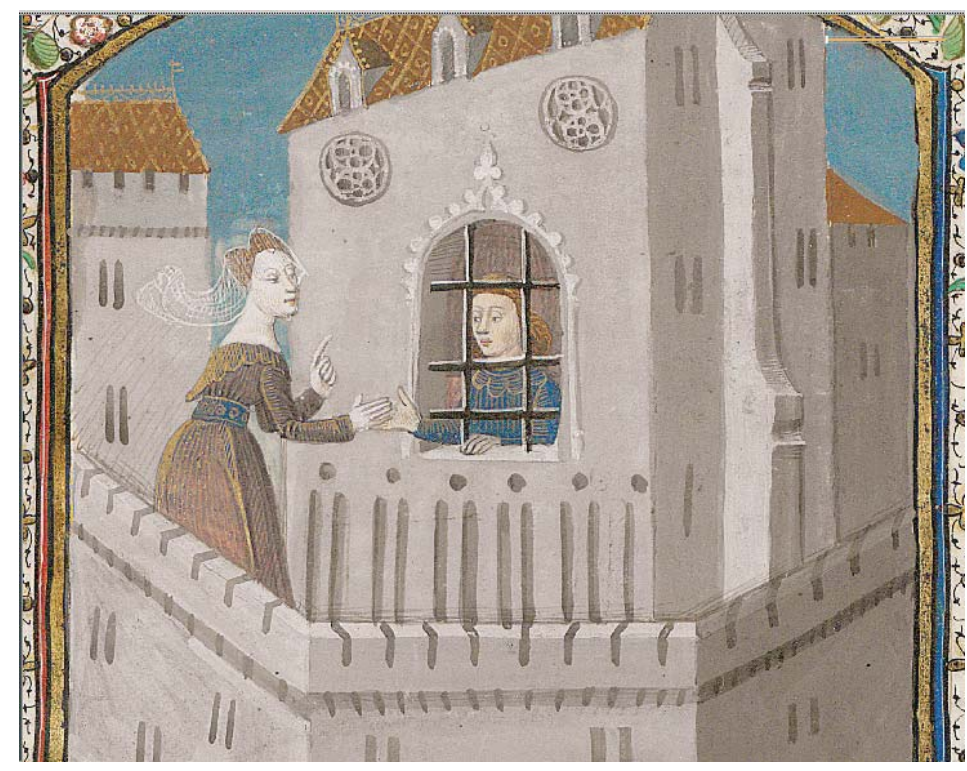

Fig. 1. Lanzarote preso por Morgana (Lancelot du Lac, siglo XIII, BNF: mss. fr. 114).

9 idem., p. 865

10 idem, p. 866.

11 idem, p. 867 
Y así lo hará el caballero. Liberado Galván, volverá Lanzarote a la prisión, en la que permanece tanto tiempo que pierde salud y belleza, y nada de lo que ve le da alegría porque está lejos de su dama. Y para salir de esta segunda prisión, vuelve a producirse un pacto entre Lanzarote y Morgana (que se ha hecho gracias a un encantamiento con el anillo que la reina Ginebra le regaló a su enamorado y con la que espera deshonrarla en la corte del rey Arturo), que se establece en los siguientes términos, como explica el propio caballero andante: "Ayer por la tarde me dijisteis que me dejaríais ir si os juraba que no entraría en ningún lugar en el que estuviera mi señora la reina, desde ahora hasta Navidad: estoy dispuesto a cumplir el juramento" ${ }^{12}$. Pero Morgana solo lo acepta cuando recupere la salud, que es el momento elegido para ilustrar esta segunda prisión de Lanzarote del Lago (figura 2).

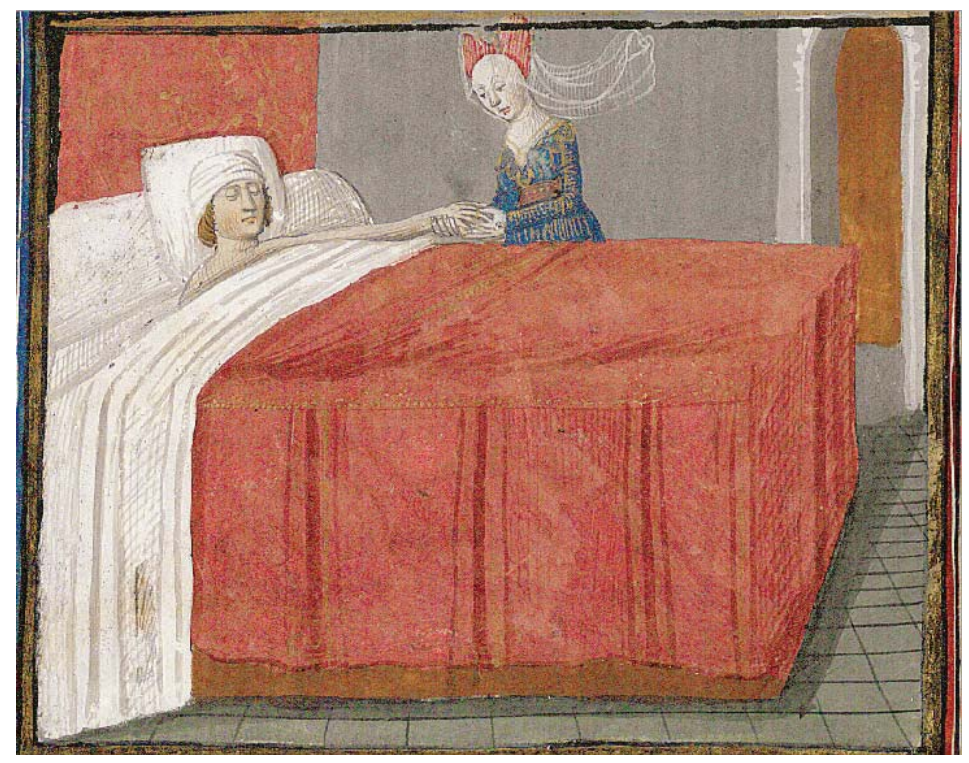

Fig. 2. Lanzarote curado por Morgana (Lancelot du Lac, siglo XIII, BNF: mss. fr. 114)

La tercera prisión de Lanzarote en manos de Morgana es la que más interesa y se narrará varias aventuras más adelante, cuando Lanzarote - que no recuerda nada de lo sucedido anteriormente- es llevado por una doncella a un rico palacio en medio del bosque. Al llegar a "una casa fuerte y rica, rodeada de murallas y fosos", es recibido con todos los honores y después de cenar en abundancia, solicita permiso para irse a la cama, pues, raro en él, se siente cansado y tiene sueño. Nada extraño si conociera la naturaleza del líquido dulce que ha tomado al final de la cena en una copa de plata: una pócima preparada por Morgana para adormecerle.

12 idem, p. 904 
Por la noche, mientras el caballero duerme y después de haberle dado otro encantamiento (esta vez unos polvos que, dentro de un tubo de plata, le mete por la nariz, soplándole hacia el cerebro), le llevan a una nueva habitación del palacio

"fuerte, grande y ancha que tenía diez toisas de ancho y veinte de largo, con ventanas enrejadas que daban a su jardín; hace que le pongan una cama tal como si el rey Arturo fuera a dormir alli'"13.

Y allí permanecerá preso Lanzarote desde el mes de septiembre hasta Navidad, sin conocer que es Morgana quien le tiene preso. Una mañana después de Pascua, "cuando el frío ya había pasado", Lanzarote se acerca a una ventana y ve cómo un hombre estaba pintando en una pared una historia antigua y que debajo de cada una de las escenas ponía un letrero, y no era otra que la historia de Eneas, de cómo huyó de Troya. Y entonces Lanzarote encuentra un modo de hacer más llevadera su prisión:

"Entonces piensa que si la habitación en la que estaba estuviera pintada con sus hechos y sus dichos, le agradecía mucho ver el elegante aspecto de su dama y le serviría de gran alivio para sus males" ${ }^{14}$.

Y así lo hizo. Le pidió al pintor sus colores y los utensilios necesarios, y comenzó a pintar

“primero cómo su Dama del Lago lo envió a la corte para ser caballero novel y cómo llegó a Camalot; cómo se quedó sorprendido por la gran belleza de su señora cuando la vio la primera vez y cómo acudió en socorro de la doncella de Nohaut".

Todo el día pintando, tanto las imágenes como los letreros. Y la causa de su vida, de poder soportar la prisión con la imagen de su amada, será también la causa de su desdicha pues, Morgana, al ver por la noche la perfección de las pinturas, concibe el plan final de su engaño, de la desgracia del rey Arturo:

"-Ahora no dejaré en modo alguno de tener prisionero al pintor hasta que haya terminado con toda la habitación, pues estoy segura de que pintará todos sus hechos y todos sus dichos y todas las obras habidas entre él y la reina; cuando lo haya hecho me esforzaré para que mi hermano el rey Arturo venga aquí y le mostraré los hechos y la verdad de la relación de Lanzarote con la reina"15

Y durante los siguientes días, Lanzarote repite el mismo ritual: lo primero que hace por la mañana será entrar en la habitación pintada y acercarse ante el retrato de la reina Ginebra: "se inclina, la saluda, se acerca a ella, la abraza y la besa en la

13 idem, p. 5137.

14 idem, p. 1538.

15 idem, p. 1539 


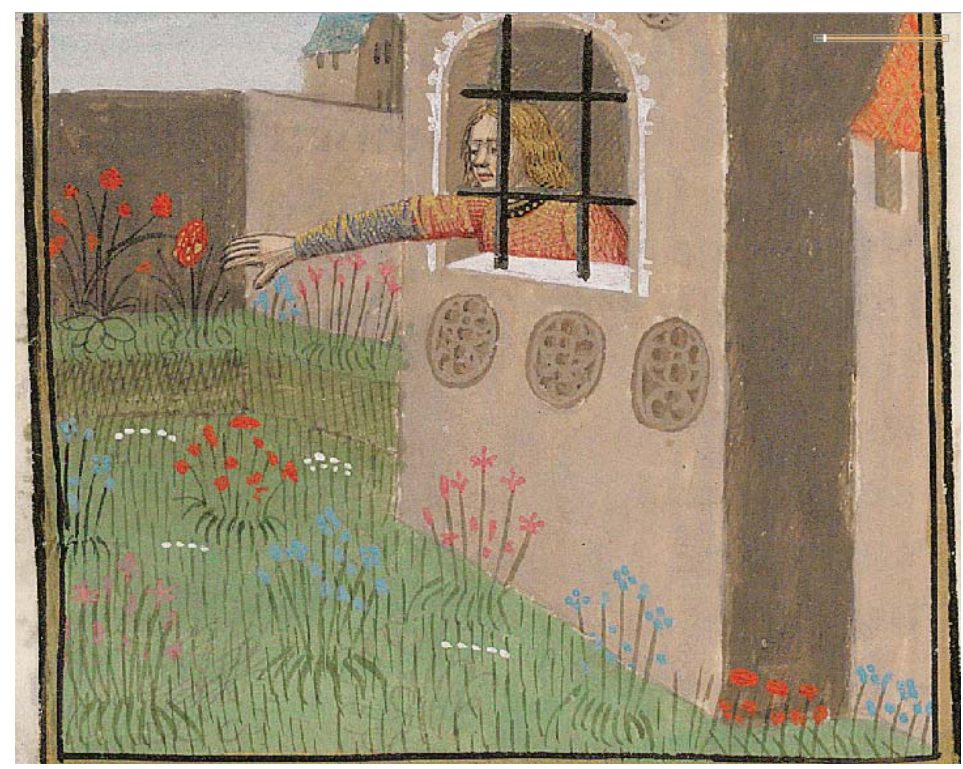

Fig. 3. Lanzarote intenta coger la rosa en el jardín de su prisión (Lancelot du Lac, siglo XIII, BNF: mss. fr. 115).

boca, deleitándose bastante más que si fuera cualquiera otra mujer" ${ }^{\prime 1}$. Y luego sigue pintando el resto de sus hazañas:

“cómo llegó a la Dolorosa Guardia y cómo conquistó el castillo gracias a su valor. El día siguiente pintó todo lo que hizo hasta el torneo que llevó las armas rojas, el día que el rey de los Cien Caballeros lo hirió. Luego pintó, de día en día, toda la historia, no solo suya, sino de todos los demás, tal como el libro ha contado".

Durante dos inviernos y un verano permanece encerrado Lanzarote en la prisión de Morgana. Las imágenes que había ido pintando en las paredes serán sus compañeros de este infortunio y su amada, desde la fría pared, le hace compañía:

"Todas las mañanas, al levantarse, iba a ver las figuras que representaban a la reina y las besaba en los ojos y en la boca, como si fuera su señora la reina; lloraba y se lamentaba con amargura. Después de lamentarse y quejarse por su desgracia durante un buen rato, volvía de nuevo a las imágenes y las besaba mostrándoles el mayor honor que podía y así se consolaba a sí mismo y era la cosa que más le agradaba" ${ }^{17}$.

Un día de mayo, cuando el jardín de Morgana estaba en todo su esplendor, vio una rosa, la más hermosa de las rosas, recién abierta: “-Del mismo modo vi a mi señora

16 idem, p. 1540

17 idem, p. 1545 


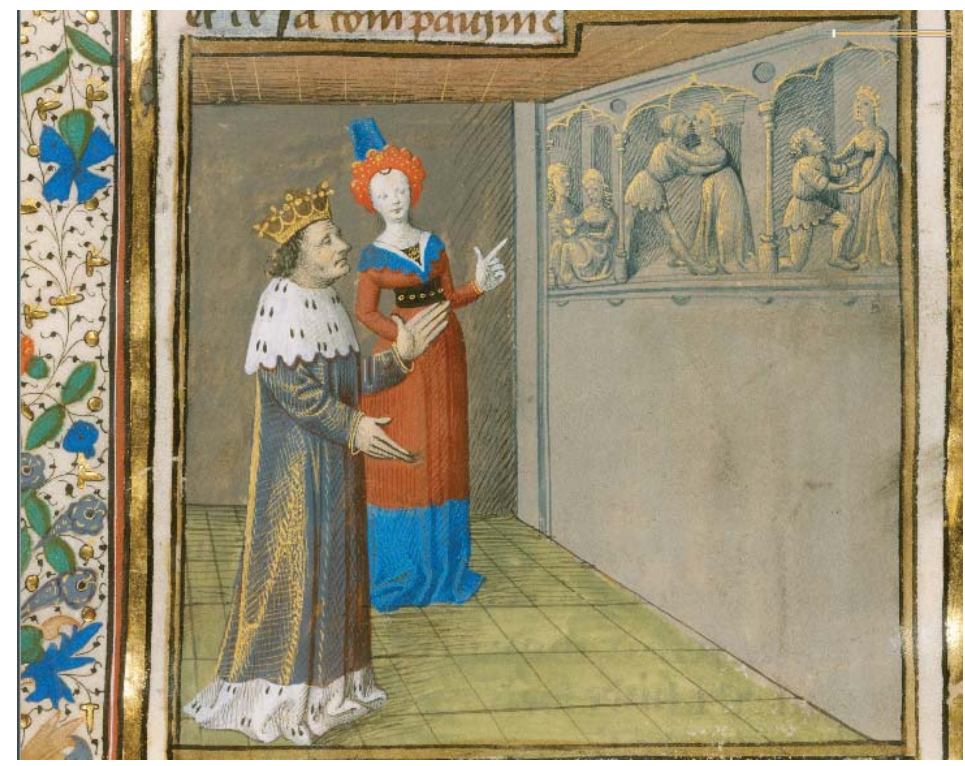

Fig. 4. El rey Arturo presencia los muros de la habitación pintada por Lanzarote (Lancelot du Lac, siglo XIII, BNF: mss. fr. 116).

más hermosa que las demás en torneo de Camalot, y ya que no la puedo tener a ella, debo tener esta rosa que tanto me la recuerda".

Pero, así como su amada está lejos y solo las imágenes pintadas en las paredes dan la apariencia de cercanía, así la rosa está ahí, a unos pocos centímetros de sus dedos... cerca pero inalcanzable. " $-i$ Qué es esto? ¿Acaso me podrá impedir una fortaleza que no yo haga mi voluntad? Ciertamente, no"

Y nada más expresar su rabia con palabras, lo hará con la fuerza, cogiendo los dos hierros de la reja con las manos y tirando de ellos con tanto empeño que termina por arrojarlo en medio de la habitación. Después del polvo, del ruido, Lanzarote mira el hueco en la ventana y allí la ve: la rosa hermosa, la rosa inmaculada. Su libertad para poder reunirse con su amada, con la verdadera, dejando a sus espaldas las imágenes, la representación en las paredes de su mundo, de sus aventuras, de su amor. Y este será el momento elegido para ilustrar el episodio, el momento del deseo, de la voluntad amorosa que termina por destruir prisiones (imagen 3).

Tiempo después, el rey Arturo llega al palacio en medio del valle y allí se reencuentra con su hermana Morgana, a la que creía muerta. Allí se cuentan sus vidas y sus aventuras y allí, una mañana más luminosa que las demás, el "rey empezó a mirar a su alrededor y vio las pinturas e imágenes que Lanzarote había dibujado cuando estuvo allí prisionero". El rey, que sabía de letras como el que más, no tuvo problemas para leer los letreros que acompañaban a las imágenes y rápidamente identificó

18 Idem, p. 1545. 
a Lanzarote y sus hazañas, de las que tenía noticia en la corte de Camalot nada más haberse realizado. Y así llega a las imágenes de la revelación de Galeote, que es el momento elegido por ilustrar el episodio, la primera imagen de la habitación pintada (figura 4).

“-Por mi fe, si es cierto lo que dicen estas letras, Lanzarote me ha afrentado con la reina; creo que tienen relaciones y, si es verdad, tal y como lo testimonia esta escritura, es la cosa que me va a causar el mayor duelo, ya que Lanzarote no podría deshonrarme más que traicionándome con mi mujer" 19 .

Y Morgana le cuenta al rey Arturo cómo Lanzarote se había enamorado de la reina nada más conocerla, cómo por ella realizaba las más sorprendentes hazañas y salía vencedor de todas las aventuras, y cómo la reina había caído en su poder por un beso, un beso al que le habían llevado las súplicas de Galeote, que veía cómo Lanzarote se consumía por su amor no correspondido. Un beso que se representa en la parte central de los frescos pintados por Lanzarote y hora vistos por el Rey Arturo. Beso que con idéntico gesto aparece en el BNF fr. 113 (figura 5).

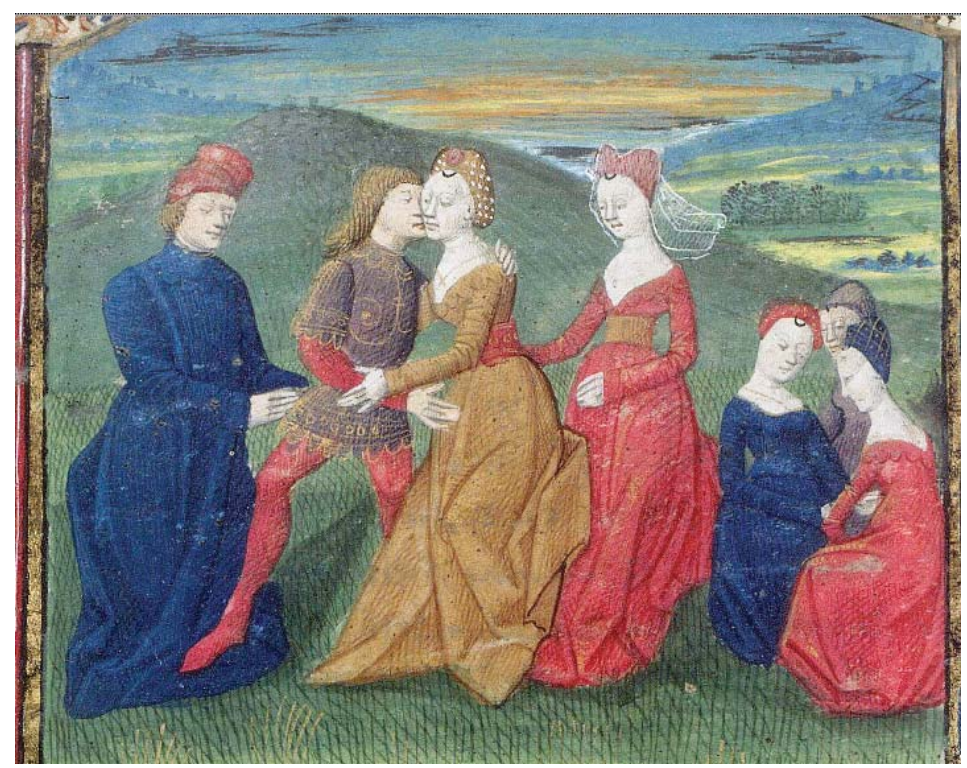

Fig. 5. Primer beso entre la reina Ginebra y Lanzarote (Lancelot du Lac, siglo XIII, BNF: mss. fr. 113).

Una flecha de odio cruzó el corazón del rey Arturo, que no pudo seguir escuchando las acusaciones de Morgana, los hechos por ella contados que estaban convertidos en imágenes en las paredes. Y así, el rey Arturo, paseándose por la habitación, sin poder

19 C. ALVAR (trad.), La muerte del rey Arturo, Madrid, 1984b, p. 57 
dejar de mirar con tristeza lo allí pintado, sin dejar escapar más de una lágrima mientras meditaba, dijo a su hermana mirándola a los ojos, interrumpiendo su cascada de secretos:

“-Ya me lo contó anteayer el propio Agraváin, pero no lo creí; antes bien, pensé que me estaba mintiendo; esto da certeza a mi corazón que antes no tenía, por eso os digo que jamás estaré a gusto en tanto no sepa la pura verdad. Y si es tal como estas imágenes lo atestiguan, y Lanzarote me ha causado tal afrenta como es deshonrarme con mi mujer, no descansaré hasta que no sean detenidos en flagrante delito y no volveré a llevar corona si entonces no empleo tal justicia que de ella se hable durante el resto de los días" 20

Frescos en las paredes que le dieron la vida a Lanzarote mientras estuvo allí preso. Imágenes que le permitieron tener cerca de su amada cada día, besarla cada mañana, hablar con ella y compartir con su retrato tantas intimidades. Imágenes que dejan huella y recuerdo, archivo iconográfico de lo que son las aventuras escritas que triunfaron en Europa durante toda la Edad Media, y pusieron las bases para su éxito posterior gracias a la multiplicación de los libros impresos. Imágenes que serán la prueba de la traición del mejor de los caballeros del mundo. Imágenes que quebraron los cimientos de la corte del rey Arturo y de los caballeros de la Mesa Redonda. Imágenes que viven, que dialogan con sus interlocutores de muy diferente manera según el tiempo, según la época, según las intenciones. Imágenes que dan la vida o que la quitan. Imágenes de vida y de muerte.

\section{Castel Roncolo: un programa iconográfico "ennoblecedor"}

Como tantos otros castillos de la zona de Bolzano y del Alto Adige, en el norte de Italia, Castel Roncolo fue construido por familias nobiliarias como defensa de los intereses o del emperador o del príncipe Obispo de Trento ${ }^{21}$. En este caso concreto, los señores de Vanga serán sus promotores y hemos de remontarnos al año de 1237 para encontrar la fecha de su edificación. Con el tiempo, llegó a ser propiedad de Meinardo II, conde de Tirol. Pero la forma actual del castillo, tanto en su exterior como en el programa iconográfico interior, es obra de los hermanos Franz y Niklaus Vintler, unos ricos comerciantes de Bolzano con aspiraciones nobiliarias, que lo adquirieron en 1385. Además de recursos económicos, los hermanos Vitler estaban muy bien situados en las intrigas políticas del momento: Niklaus fue consejero y persona de confianza del duque Leopoldo.

Castel Roncolo se convierte de la mano de los Vitler en residencia de verano y en representación de sus deseos ennoblecedores, de ahí el programa iconográfico que se puede admirar en las paredes de sus dos grandes edificios, los conocidos como

20 idem, p. 57

21 Para más detalles, véase C. DEMATTÈ y J.M. LUCÍA MEGÍAS, “Immagini di dame e cavalieri: affreschi cavallereschi ed arturiani in Trentino Ato Adige (presentazione di un progetto internazionale)", C. DEMATTÈ (a cura di), Il mondo cavalleresco tra immagine e testo, Trento, 2010, pp. 13-44. 
Palacio Occidental y Casa de Verano (de nueva construcción por los Vitler), con el corredor que une ambos. Un programa iconográfico, un palacio pintado que dibuja en los muros el tipo de vida a la que aspiran los Vitler, la que sueñan como modelo nobiliario. Escenas de la vida cotidiana de la nobleza del siglo XIV con algunas de sus lecturas caballerescas más habituales y populares. Y todo ello, mezclado con unas salas cuyas pinturas todavía siguen siendo un misterio, unos motivos iconográficos que no han sido desentrañados totalmente en la actualidad. Un rápido paseo por estas imágenes del siglo XIV en el norte de Italia permite rememorar el valor de representación de la iconografía caballeresca en los palacios pintados, su función medieval más allá de los valores artísticos, filológicos o turísticos de los que se han llenado en la actualidad.

El primer piso del palacio occidental se le conoce como "Sala de los caballeros" $\mathrm{y}$, por su emplazamiento a pie de tierra, es uno de las peores conservadas, de las que más ha sufrido el abandono del castillo a lo largo de los siglos. Lo mismo puede decirse de la primera de las salas del segundo piso: la "Sala de los juegos", en la que, a pesar de los deterioros, pueden identificarse diferentes escenas lúdicas de los nobles de la época, con una representación del propio Castel Roncolo, en una autorepresentación tan propia de la época y que encontraremos en otros palacios pintados de la zona. De ahí, subiendo al tercer piso, el mejor conservado, se llega a la "Sala del torneo", donde se encuentran pintadas diferentes escenas cotidianas. En la pared occidental continuando en la oriental se representan diferentes tipos de caza (figura 7): la caza del ciervo, del jabalí, del oso hasta la de la cabra montés así como una escena de pesca (figura 6). Todo está unido por paisajes y representaciones de ciudades imaginarias.

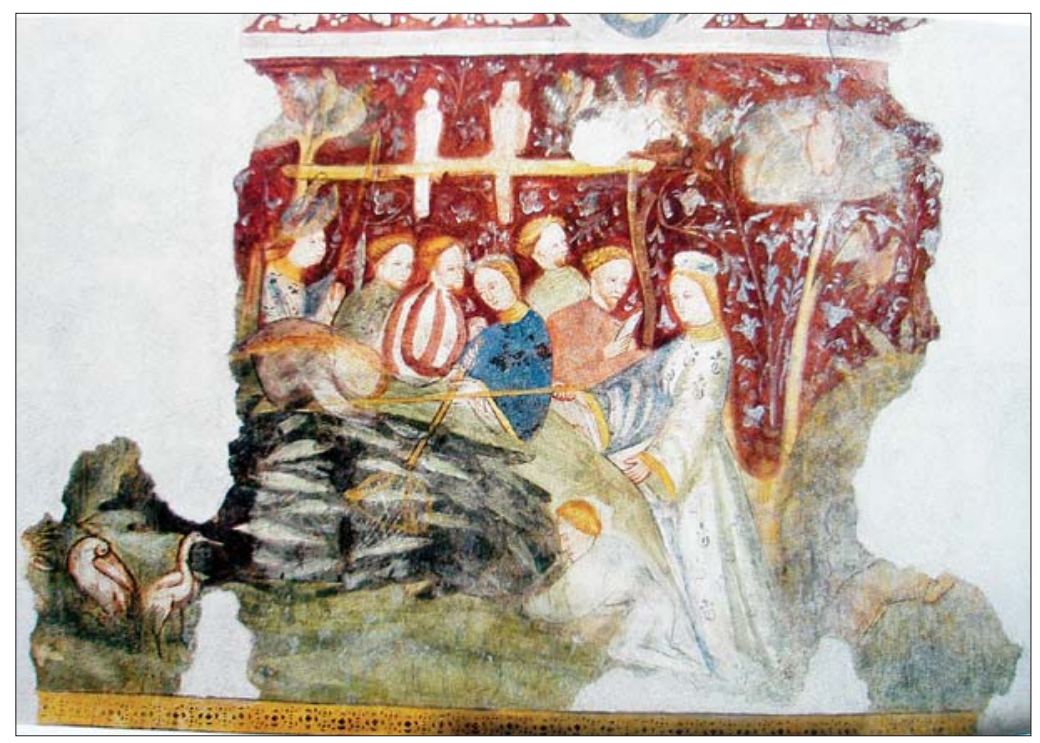

Fig. 6. Escena de pesca, en la Sala del Torneo. Palacio Occidental. Castel Roncolo (siglo XIV). 


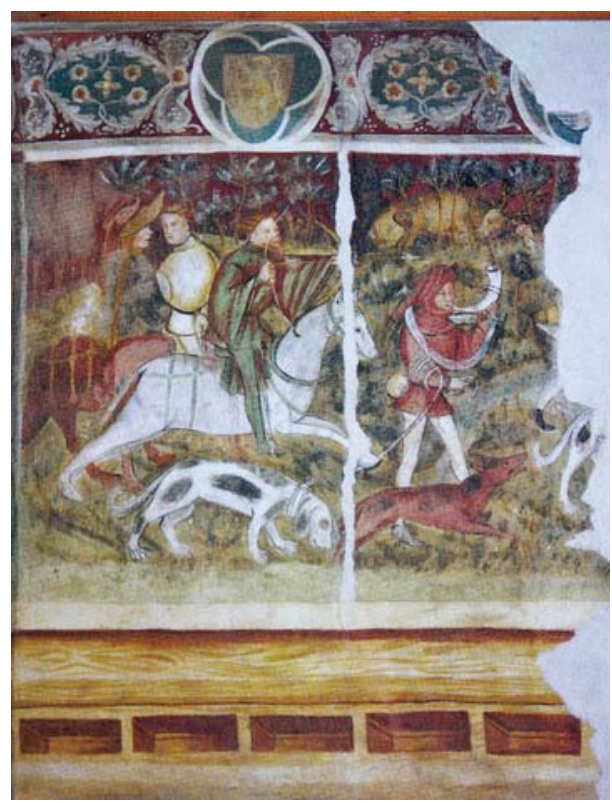

Fig. 7. Escena de caza, en la Sala del Torneo. Palacio Occidental. Castel Roncolo (siglo XIV).

Por su parte, la pared sur está dedicada a dos escenas corteses, dos escenas cotidianas protagonizadas por los mismos personajes: el juego de la pelota (figura 8) y una danza cortés (figura 9), tan habitual en muchos de las representaciones caballerescas en tantos palacios pintados en la zona, como en la Torre Aquila de Trento, o en la casa Zur Tuchlauben 19 de Viena, por ejemplo.

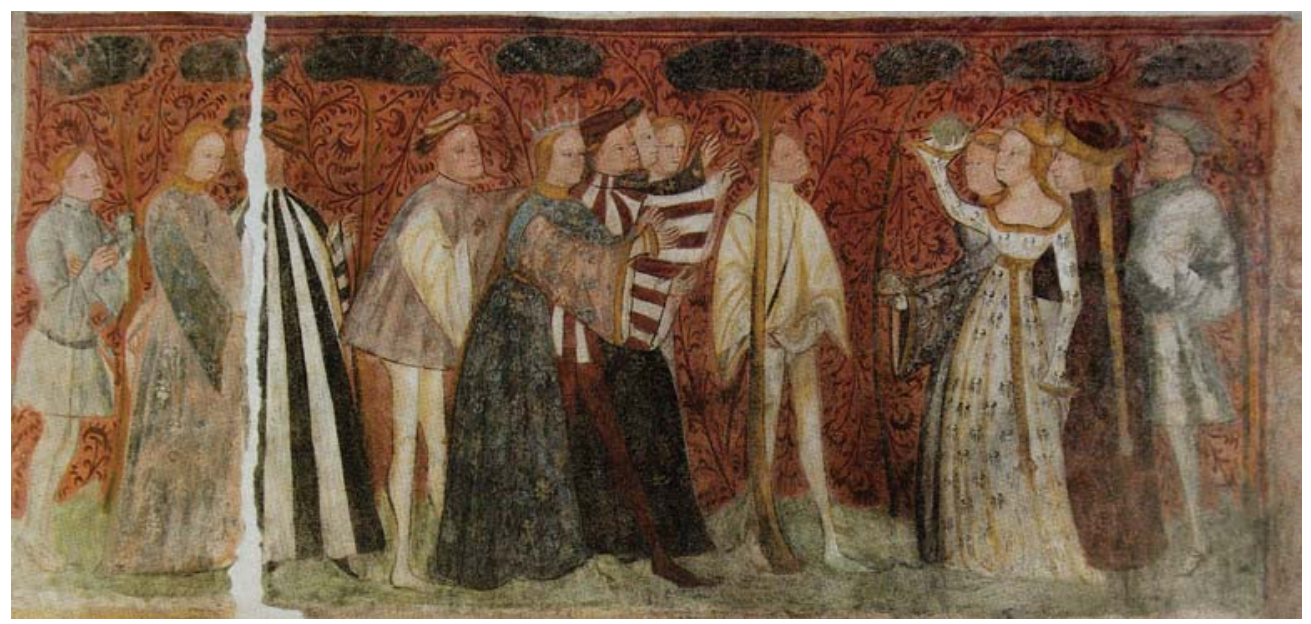

Fig. 8. Juego de la pelota, en la Sala del Torneo. Palacio Occidental. Castel Roncolo (siglo XIV). 


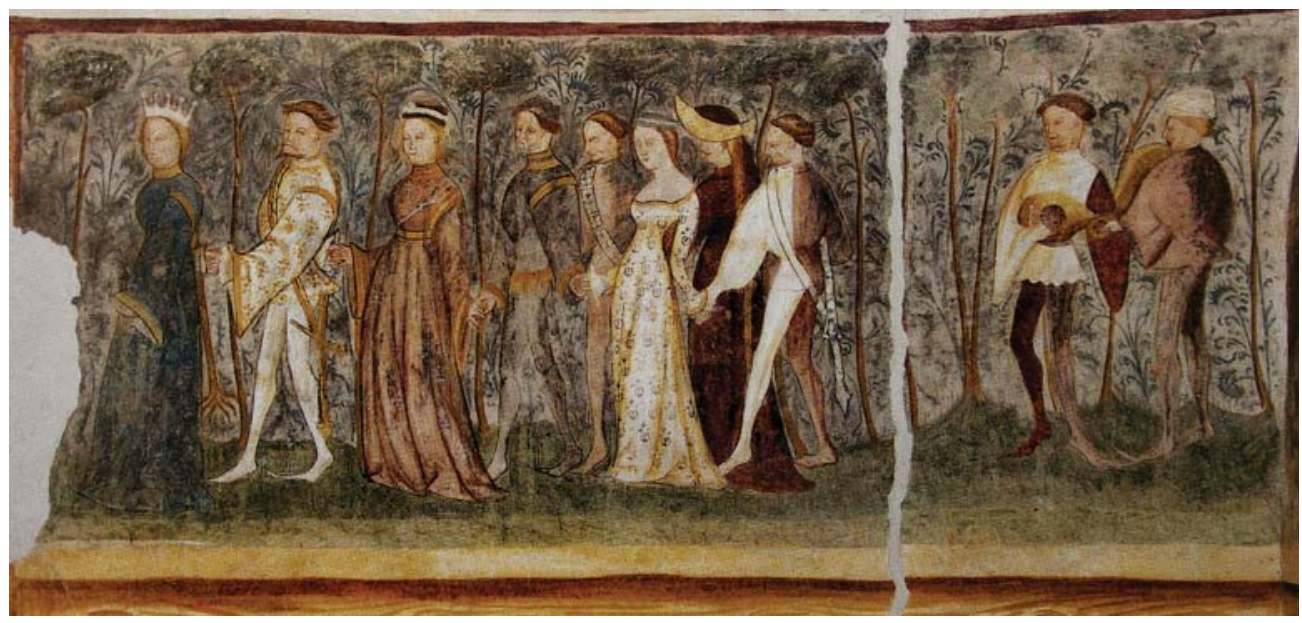

Fig. 9. Danza, en la Sala del Torneo. Palacio Occidental. Castel Roncolo (siglo XIV).

Escenas cortesanas, lúdicas, donde los personajes aparecen retratados en diferentes acciones; personajes que, con sus ricos vestidos y características sedas, estarían vinculados a los Vitler, a los nobles y burgueses que habían convertido Castel Roncolo en un lugar propicio para la diversión en los calurosos veranos de finales del siglo XIV.

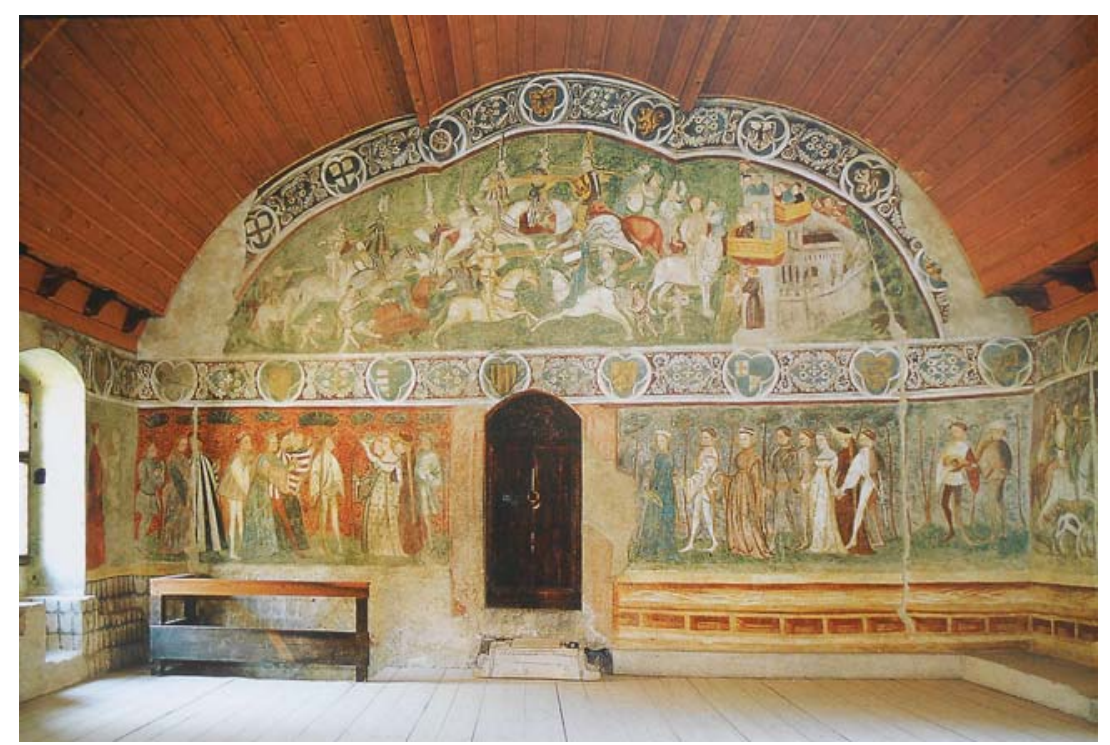

Fig. 10. Sala del Torneo. Vita general de la pared norte. Palacio Occidental. Castel Roncolo (siglo XIV). 


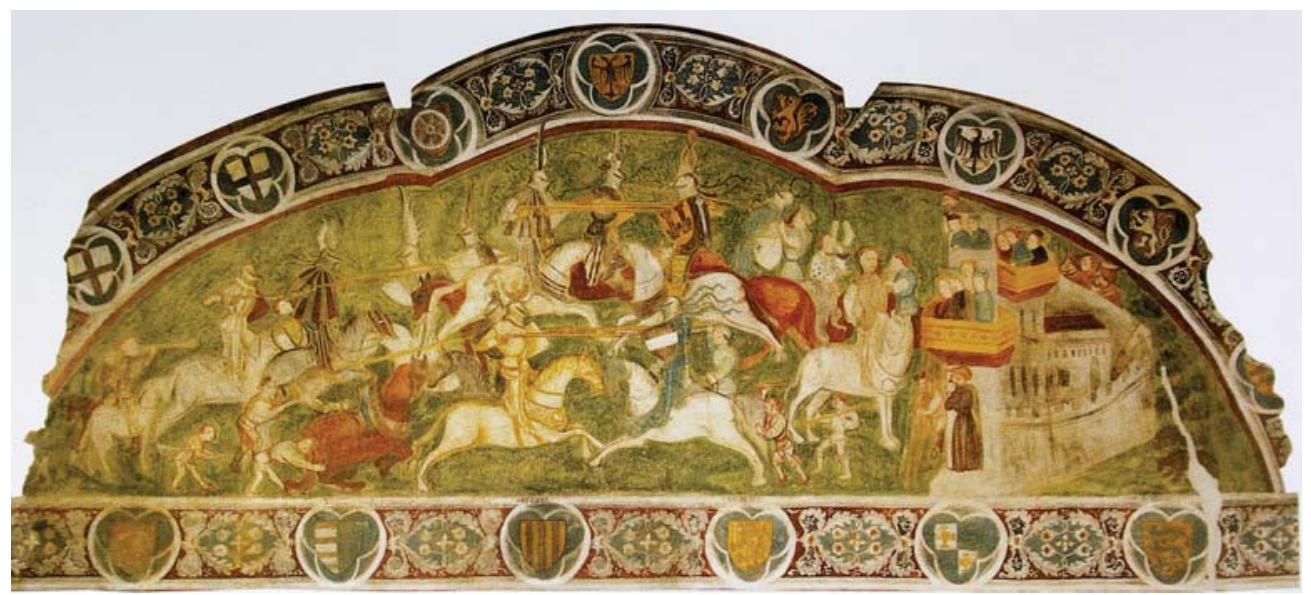

Fig. 11. Torneo con lanzas, en la Sala del Torneo. Palacio Occidental. Castel Roncolo (siglo XIV).

Pero si en las paredes inferiores se representan diversas escenas corteses, así como variados tipos de caza, el nombre de la sala (figura 10) hace alusión al magnífico fresco en la parte superior de la misma que representa un torneo con lanzas (figura 11): elemento esencial en la vida caballeresca, pues en él, de una manera sin comparación, se aunan tanto el entretenimiento cortesano como la función defensiva de la caballería, su función guerrera que ya no se desarrolla en largas campañas militares sino en espectáculos cada vez más reglados, más cortesanos, pero donde el peligro siempre está presente.

El torneo de lanzas representado en la sala principial del Palacio Occidental del Castel Roncolo está lleno de detalles cotidianos que, por falta de espacio, no es posible comentar, pero que hacen de esta representación una de las más interesantes de las que se pueden encontrar en el norte de Italia.

En la parte central, es posible identificar tres escenas de combates y duelos. En primer plano, dos caballeros que se enfrentan en combate singular, y que representan al Duque de Austria y a Alberto II de Habsburgo (figura 12). Junto al duque de Austria se aprecian dos escuderos, en un detalle realista de la representación: uno de ellos lleva una lanza de reserva, y el otro, de pie, está azuzando al caballo de su señor en el momento decisivo del combate. Detrás de ellos, otros tres combates singulares con lanza, con diferente desarrollo. Llaman la atención los detalles cotidianos, como la ayuda que prestan los escuderos a los caballeros que han sido acertados con las lanzas para poder volverlos a su posición vertical, que se aprecia tanto en la parte izquierda como al fondo a la derecha. Y por último, justo al lado de la representación del castillo, un caballero que está siendo armado por sus escuderos (figura 13). 


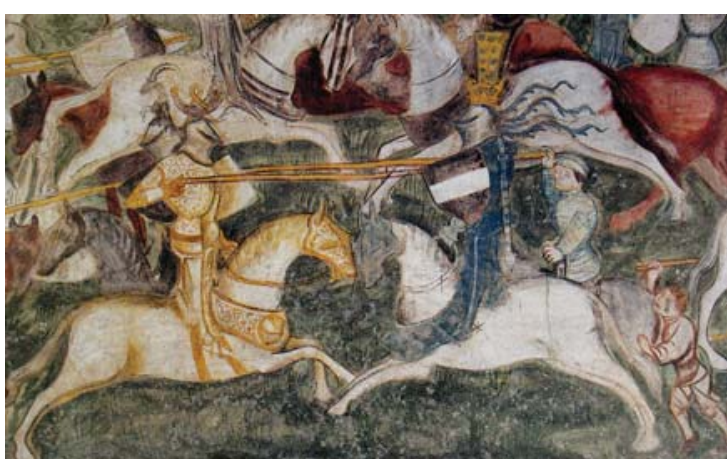

Fig. 12. Combate singular (detalle), en la Sala del Torneo. Palacio Occidental. Castel Roncolo (siglo XIV).

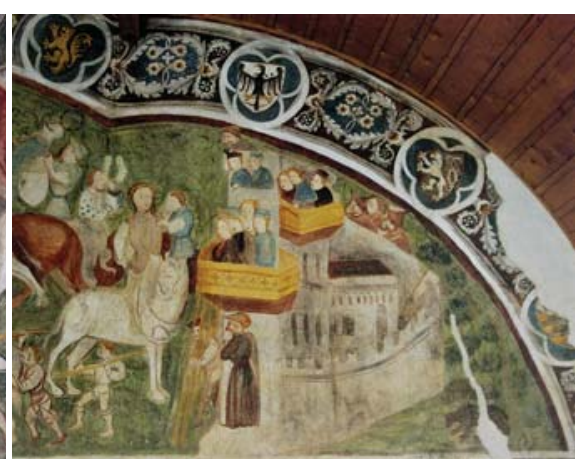

Fig. 13. Caballero siendo armado (detalle), en la Sala del Torneo. Palacio Occidental. Castel Roncolo (siglo XIV).

En la siguiente sala, la conocida como "Sala de las parejas", en el mismo espacio, se hará la representación de otro tipo de torneos: el torneo con espadas y mazas (figura 14).

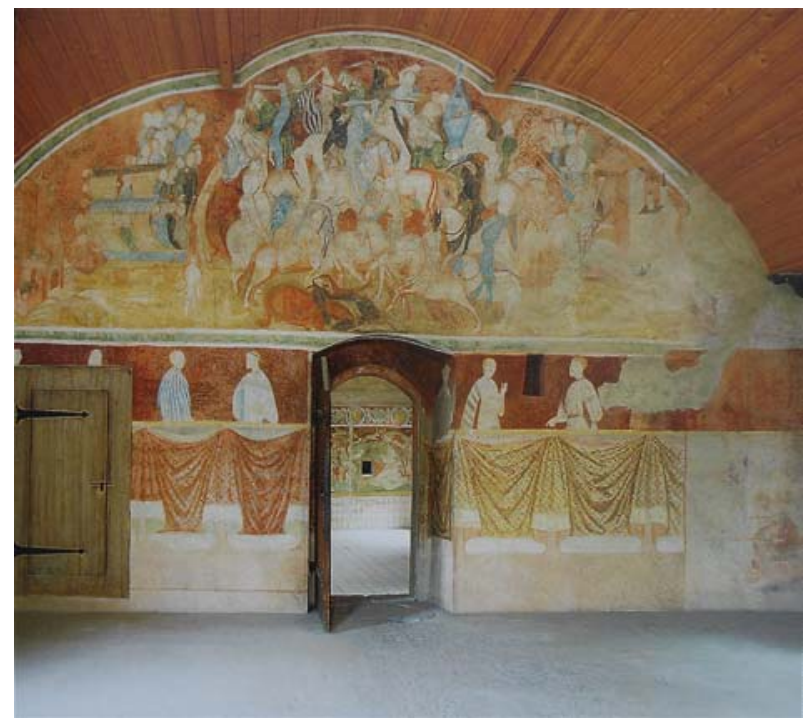

Fig. 14. Torneo de espadas, en la Sala de las parejas. Palacio Occidental. Castel Roncolo (siglo XIV).

Si el Palacio Occidental estará dedicado a la representación de los usos caballerescos: torneos, caza, juegos, bailes... la Casa de Verano, una ampliación que los Vitler llevan a cabo sobre el diseño original del castillo, tiene como programa iconográfica las lecturas caballerescas, el imaginario creado para dar un sentido y una unidad a 
las costumbres feudales y cortesanas imperantes durante la Edad Media. La pared externa de la Casa de Verano (figura 15), como una tarjeta de visita, se dedicará a la representación de los Nueve Caballeros de la Fama (Héctor, Alejandro Magno, Julio César, Josué, David, Judas Macabeo, el Rey Arturo, Carlo Magno, Godofredo de Bullón, Parsifal, Gauvain e Yvaín), parejas de enamorados (Guillermo de Austria y Aglei, Tristán e Isolda y Guillermo de Orleans y Amalia), los caballeros Teodorico de Verona, Sigfrido y Dietleib de Stiria, los gigantes Waldram, Ornit y Shrautan, las gigantes Ruel, Ritsch y Rachin, para terminar con los enanos Goldemar, Bibunch y Alberich. Todos ellos representando en grupos de tres.

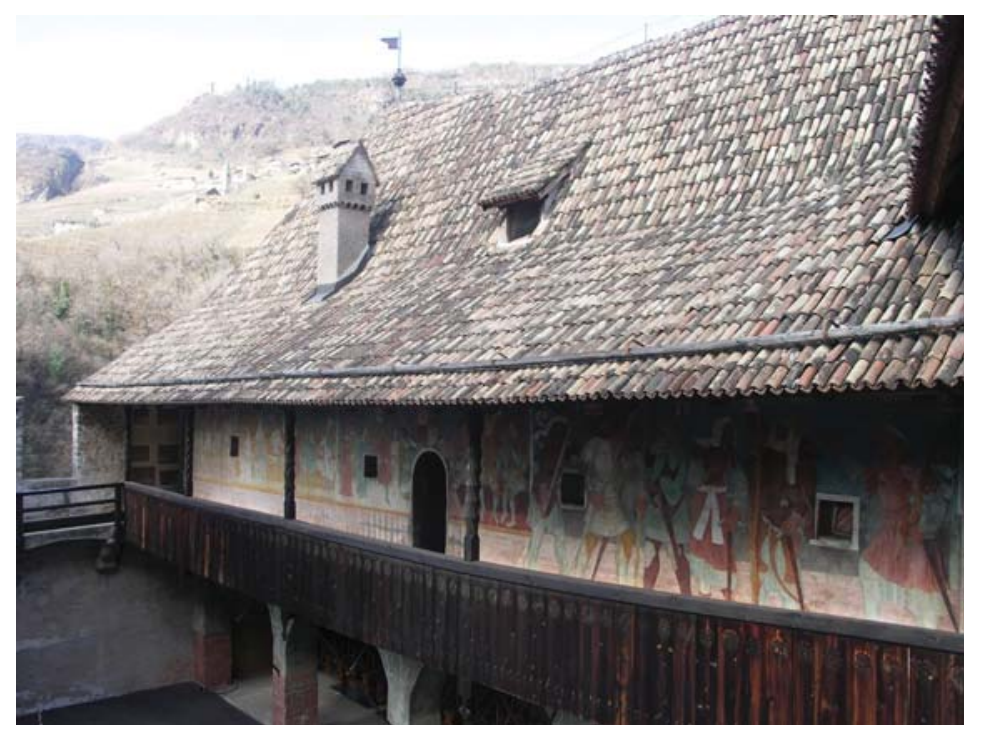

Fig. 15. Corredor de entrada de la Casa de Verano Castel Roncolo (siglo XIV).

En el interior de la Casa de Verano encontraremos dos series de frescos que ilustrarán las aventuras de Tristán (figura 16) y de Garelo (figura 17), que tuvieron un gran éxito en la zona, tanto en sus originales franceses como en las tempranas traducciones al alemán ${ }^{22}$. El piso inferior de la Casa de Verano estaba dedicado a un tercer ciclo literario, que tenía como protagonista a Wigalois, un roman alto-alemán del siglo XIII. $\mathrm{Al}$ estar situado en la planta baja y en una parte que sufrió en el siglo XIX diversos cambios estructurales, se ha perdido casi todo el ciclo, aunque los dibujos realizados por Ernst Karl von Waldstein en 1892, permite imaginar hoy en día el aspecto monumental de otros tiempos ${ }^{23}$.

\footnotetext{
22 Para una reproducción y estudio de todo el ciclo profano, véase K. DOMANSKI y M. KRENN, "I cicli profani nella casa d'estate", Castel Roncolo. Il maniero illustrato, pp. 99-154

23 Un análisis de los mismos, con excelentes reproducciones, puede consultarse en A. GRÄBER, "Il ciclo di Wigalois a Castel Roncolo", Castel Roncolo. Il maniero illustrato, pp. 155-171.
} 


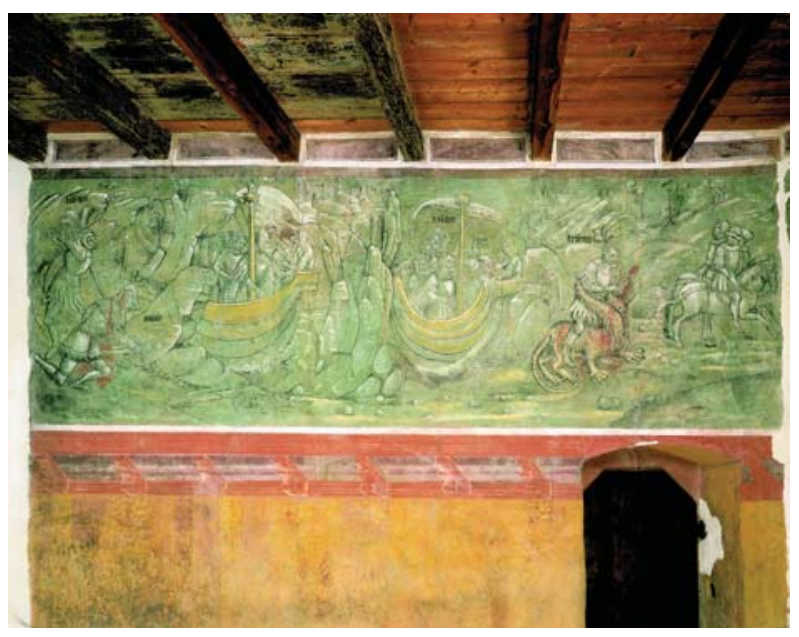

Fig. 16. Ciclo del Tristán en la Casa de Verano Castel Roncolo (siglo XIV).
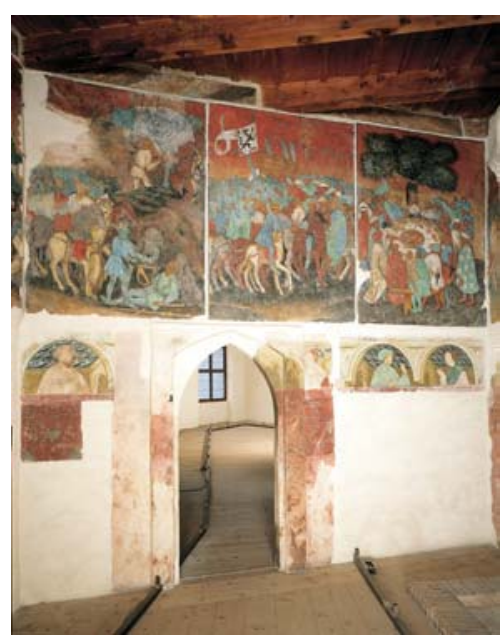

Fig. 17. Ciclo del Garelo en la Casa de Verano Castel Roncolo (siglo XIV).

El programa iconográfico ideado por los Vitler para Castel Roncolo no se limita a estos dos ejes habituales en los palacios pintados de la zona: representaciones de la vida cortesana y aventuras de los héroes de pergamino, de aquellos que permitan soñar con otros mundos, que otros mundos son posibles. Ni mucho menos.

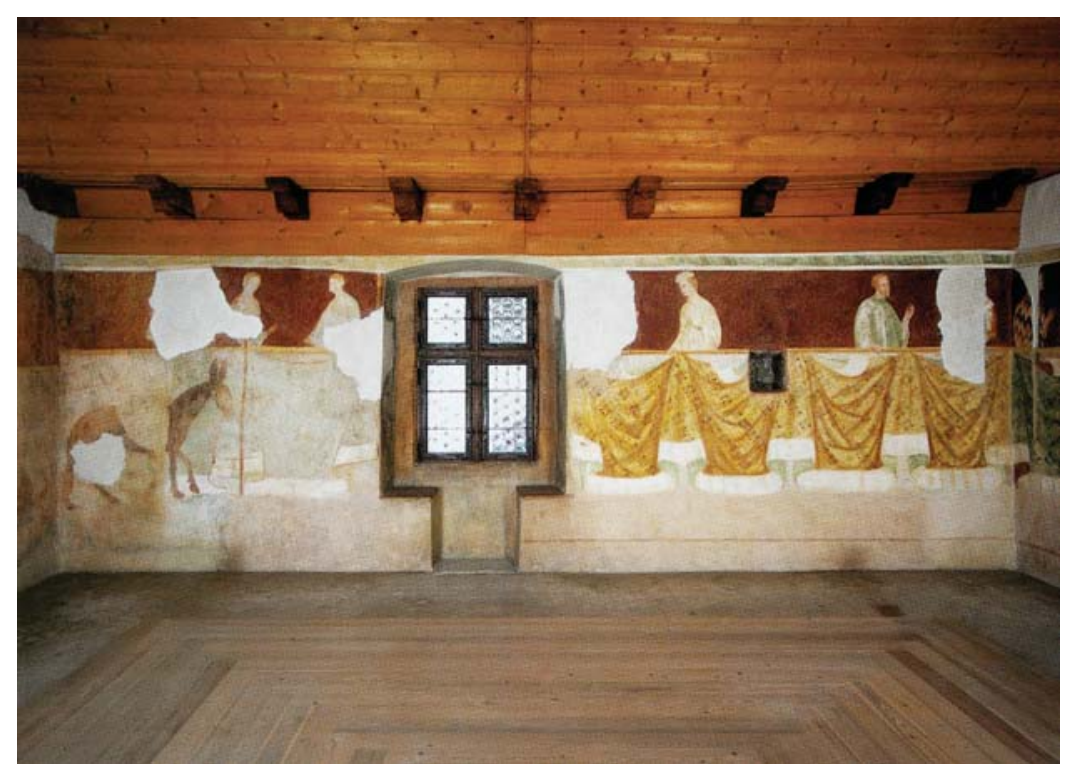

Fig. 18. Sala de las parejas, en el Palacio Occidental. Castel Roncolo (siglo XIV). 


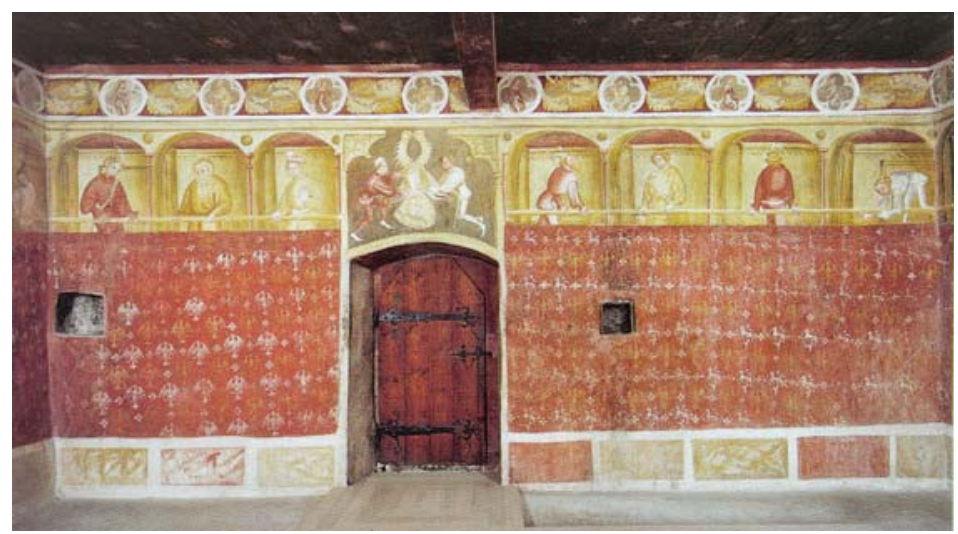

Fig. 19. Sala del baño (norte), en el Palacio Occidental. Castel Roncolo (siglo XIV).

En el Palacio Occidental hemos dejado sin tratar dos salas, al norte de la "Sala de los Juegos" y la "Sala del Torneo". Detrás de la "Sala del Torneo", la que representa el torneo con espadas y mazas, se encuentra la conocida como "Sala de las Parejas", pues en ella aparecen representadas en la parte superior parejas de hombres y mujeres en diferentes actitudes, dominando entre todas las de la conversación galantes (imagen 18).

Más allá de la Sala de los juegos, aparece la conocida como "Sala de los Baños", que es una de las mejores conservadas de la época de los Vitler: todavía es posible disfrutar del techo original de madera, donde se intuye la rica decoración que representa un cielo estrellado, y en el lado sudeste, el sol y la luna. La mayor parte de la decoración de la sala está dedicada a un falso tapiz de fondo rojo y sobre él, como si se tratara de una galería, una serie de personajes en distintas posiciones que observan a -y son observados por- las personas que entran en la sala. Una de las paredes estará

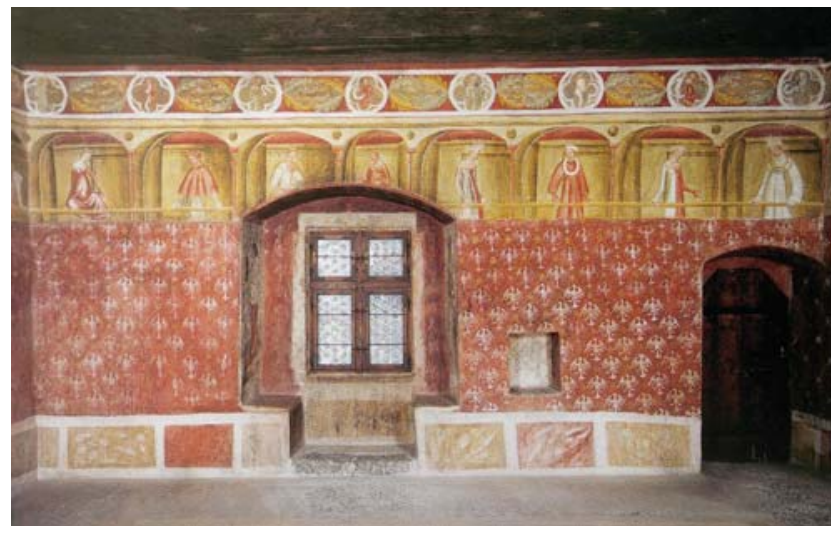

Fig. 20. Sala del baño (este), en el Palacio Occidental. Castel Roncolo (siglo XIV). 


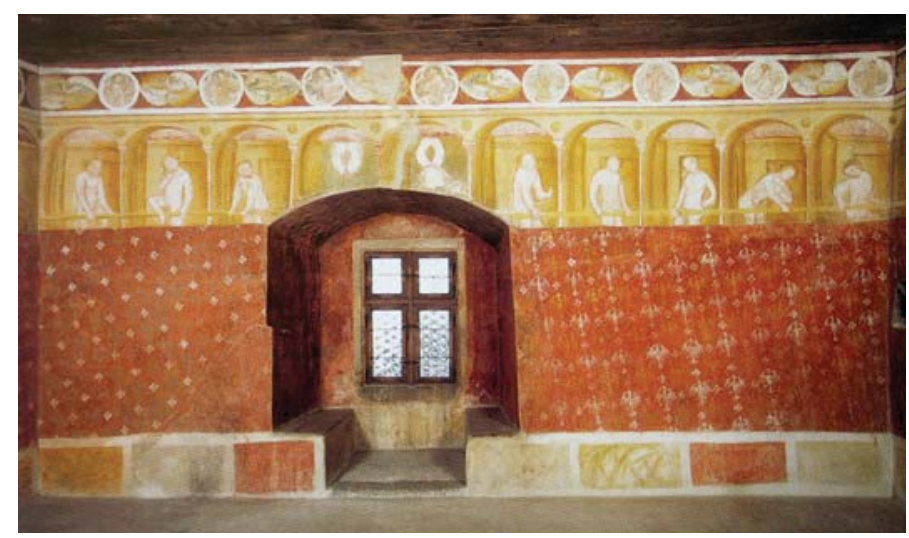

Fig. 21. Sala del baño (sur), en el Palacio Occidental. Castel Roncolo (siglo XIV).

dedicada a representación de caballeros (figura 19), otra a las damas (figura 20), otra a animales de muy diversa naturaleza (figura 21), para terminar con una galería de hombres desnudos (figura 22), que dio, de manera equivocada título a la sala, pues en un principio se pensó que representaban a hombres saliendo del baño.

Pinturas en las paredes que dan la vida, que permiten el recuerdo de las hazañas y de los seres amados. Pinturas que se convierten en la prueba de un adulterio y del principio del fin de un imperio, de un modo de entender el mundo. Pinturas que reflejan en los muros de los palacios los deseos de ennoblecerse de tantos hombres y mujeres a lo largo de los siglos: imágenes que son espejo de juegos cortesanos, de cacerías y de torneos de la época, de lecturas de algunos de los héroes más reconocidos en el tiempo, como Tristán de Leonís o el alto-alemán Garelo. Pinturas, en fin, que nos miran desde las galerías y que nos siguen fascinando con sus misterios, con sus preguntas no resueltas, con sus explicaciones que nos convierten en juguetes interpretativos del pasado.

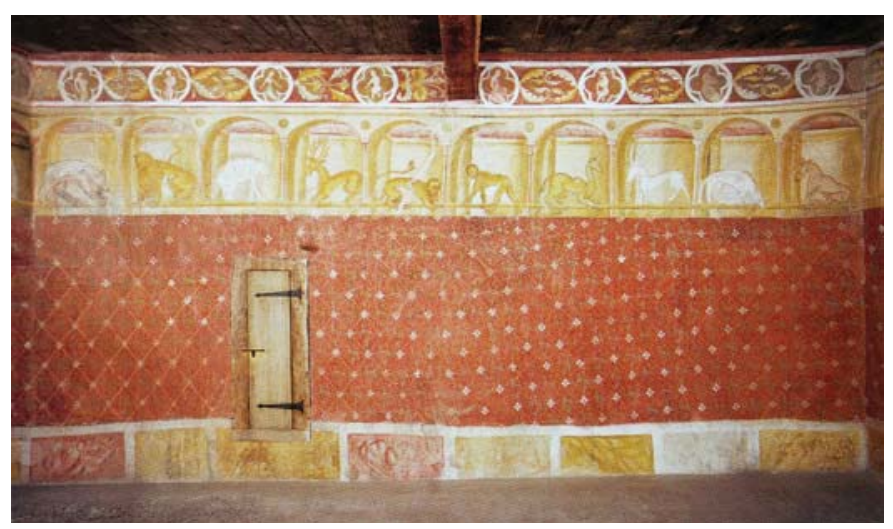

Fig. 22. Sala del baño (oeste), en el Palacio Occidental. Castel Roncolo (siglo XIV). 